\title{
COMPLIANCE WITH LABELING LEGISLATION OF THE REPUBLIC OF MOLDOVA IN THE FIELD OF CONFECTIONERY PRODUCTS
}

\author{
Cristina POPOVICI*1 ${ }^{1}$, Nina MIJA*, Adriana BIRCA*, Iulia IATCO** \\ * Faculty of Technology and Management in Food Industry, Technical \\ University of Moldova, Chisinau, Republic of Moldova \\ ** Institute of Microbiology and Biotechnology, Academy of Science of \\ Moldova, Chisinau, Republic of Moldova
}

\begin{abstract}
: this article presents the basic principles of food labeling, especially of confectionery products, such as the consumers' right to non misleading information and informed choice, and the harmonisation of national laws. The control on respecting the compliance of information written on product label is made by competent authorities for execution of official control of foodstuffs in the Republic of Moldova. The relevant national regulations are given, and references and websites given for access to full texts. The results of critical surveys on the present implementation of confectionery products labeling are summarised, together with the corresponding recommendations for improvement.
\end{abstract}

Key words: confectionery products, label information, technical regulations, national laws

\section{INTRODUCTION}

According to the Parliament Law of the Republic of Moldova nr. 78 as of 18.03.2004 "On foodstuffs", labeling (marking) is any words, trademarks, registered trademarks, signs, elements drawn or written, stamped, embossed or printed on, or attached to a container with foodstuffs and positioned on

\footnotetext{
${ }^{1}$ Corresponding author. Mailing adress: Faculty of Technology and Management in Food Industry, Technical University of Moldova, 168 Stefan cel Mare blvd., MD 2004 Chisinau, Republic of Moldova, E-mail: popovici.kristina@gmail.com
}

Vol. XVII (2013), no.2 
any packaging, accompanying document, notice, label, band or flange, which is accompanying or is referring to such foodstuff (Lege Parlament, 2004).

Labeling of confectionery products is performed in accordance with the provisions of legislative and normative acts regarding labeling, with the application of additional terms, which must be clearly visible, legible, and comprehensible and must not mislead the consumer. Informing consumers about confectionery products is carried out compulsorily, by elements of identification and by indicating their characteristics, which are on view and explicitly on the product, label, packaging (Hotărîre de Guvern, 2003).

Producer (packer) must provide information about the product name, brand and name of manufacturer, to indicate its address (telephone number, if applicable), the mass/volume, the main qualitative characteristics, composition, additives used, possible risks, how to use, handling, storage, conservation or keeping, contraindications, as well as the energy value of prepackaged foods, country of production, the term of warranty, period of duration, period of validity and date of manufacture, in accordance with national standards and technical regulations (Hotărîre de Guvern, 2009).

The control on respecting the compliance of information written on product label is made by competent authorities for execution of official control of foodstuffs in the RM: National Food Security Agency, Centre for preventive medicine of the Ministry of Health and Family, Sanitary Veterinary Authorities designated by the Ministry of Agriculture and Food Industry, etc. In this paper is made the analysis of compliance with product labeling legislation of confectionery products, produced by enterprises of the RM, such as: S.A. "Patisier"; S.A. "Camerton", S.A. "Franzeluţa", and others.

\section{PRODUCTION OF CONFECTIONARY PRODUCTS IN THE REPUBLIC OF MOLDOVA}

In the Republic of Moldova are legalized 109 enterprises specialized in the production of confectionery products. Below in Figure 1 is represented the distribution of the number of enterprises on settlements. The rest of settlements fall by 1 or 2 enterprises, among which are: Cahul, Soroca, etc. The largest enterprises are SA „Franzeluta”, SA „Bucuria”, SRL „Dulcinella”, ICS „Nefis”, SA „Camerton”, SRL „Drancor”, SA „Parisier”.

Acta Universitatis Cibiniensis Series E: FOOD TECHNOLOGY

Vol. XVII (2013), no.2 


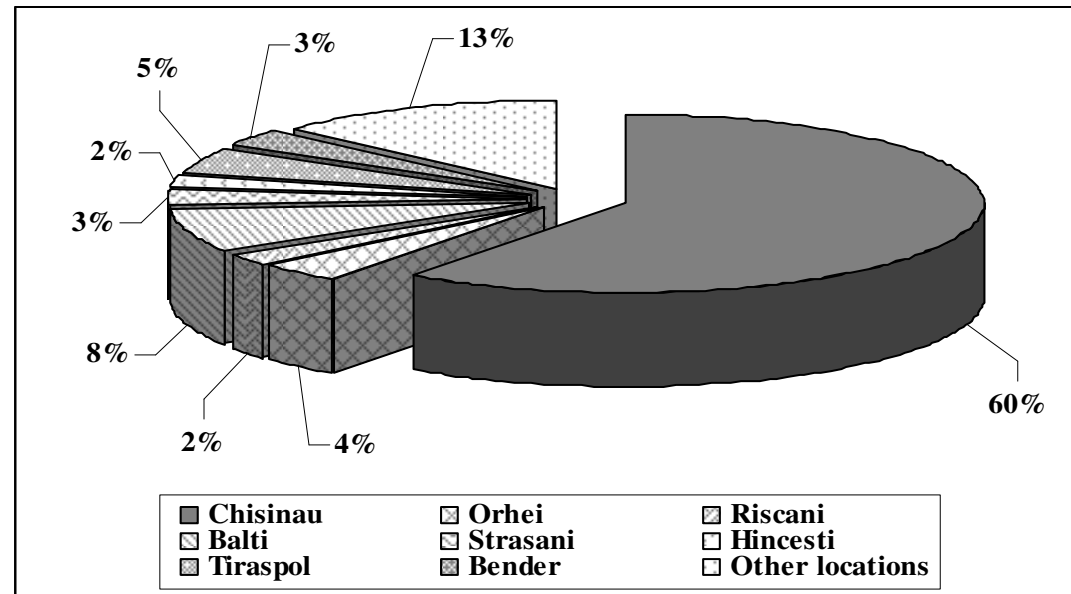

Figure 1. Distribution of enterprises specialized in the production of confectionery products on settlements as a percentage

\section{REGULATIONS ON LABELING OF CONFECTIONERY PRODUCTS IN THE REPUBLIC OF MOLDOVA}

In the Republic of Moldova confectionery product labeling is performed in accordance with the Law nr. 420-XVI as of December 222006 "On technical regulatory activity" (Monitorul Oficial of the Republic of Moldova, 2007, nr. 36-38, art. 141), with subsequent amendments and additions, the Law nr. 78-XV as of March 18, 2004 "On foodstuffs" (Monitorul Oficial of the Republic of Moldova, 2004, nr. 83-87, art. 431) and Law nr. 105-XV as of March 13, 2003 "On consumer protection" (Monitorul Oficial of the Republic of Moldova, 2003, nr. 126-131, art. 507), with subsequent amendments and additions, which was approved by the Government decision Nr. 204 as of 11.03.2009 with respect of approving the technical Regulation „Confectionery products” (Monitorul Oficial of the Republic of Moldova, 2009, nr. 57-58, art. 254), date of entry into force: 01.06.2010 (Hotărîre de Guvern, 2009), (Hotărîre de Guvern, 2011), (Lege de Parlament, 2003), (Lege de Parlament, 2004). Confectionery product labeling is performed in accordance with the Government Decision nr. 996 as of August 20, 2003 "About approval of Regulations on labeling of foodstuffs and Regulations on labeling of means household chemicals" (Monitorul Oficial of the Republic of Moldova, 2003, nr. 189-190, art.1046) (Hotărîre de Guvern, 2003).

For confectionery products labeling, commercial enterprises of food sector shall comply with the required regulations applicable in the field of food. It

Vol. XVII (2013), no.2 
is important, as the confectionery products labeling must not mislead the consumer. Labeling should provide consumers with the necessary information, sufficient, effective and easily compared, allowing them to choose the product according to the requirements and their financial possibilities, to know the possible risks which might be subjected, in order not to be misled.

The label must be placed so that it cannot be separated from the container and the information on it cannot be deleted. The label must contain the information required by the regulations in the food sector, including: the name under which the product is marketed; the list of ingredients; the net quantity, volume; the date of manufacture and date of minimum durability; conditions of storage; instructions for use; name and address of the manufacturer and/or importer, the Distributor; batch identification data; name of the country of origin; other specific information.

The information on the confectionery products label must be set on a visible place so that, in ordinary conditions of purchase and use, the consumer to be able to read and understand. It is prohibited to extend the shelf-life of food products, including repackaging or relabeling.

The confectionery product labeling are not allowed inscriptions, which assigns or suggesting that the product has properties for the treatment or prevention of disease in humans, except when these properties were demonstrated or confirmed by the Ministry of Health, and misleading the consumer by giving false information regarding the origin, identity, properties, composition, particularities the validity of the method of production and use of food, other than natural ones.

Also, it is prohibited to distribute in any form of confectionery products tagged incorrectly. Labeling of products derived from genetically modified organisms is done by registering the indication on the label: "genetically modified food" or "food made from genetically modified organisms".

\section{ANALYSIS OF COMPLIANCE WITH LABELING LEGISLATION OF CONFECTIONERY PRODUCTS (CASE STUDY)}

In this paper were examined, cake labels manufactured by confectionery companies in Chisinau in the period November-December 2012. Detailed research of labels showed the following positive trends:

- Labels for cakes contain virtually all the compulsory particulars required;

- All labels provide information concerning the nutritional value of the product;

Vol. XVII (2013), no.2 
- For product integrity (pastry cake) is indicated the list of ingredients, used for dough and the list of ingredients for cream.

At the same time it is observed a certain unjustified individualization of the content labels and quite a few inaccuracies:

- Not all labels have design, made artistically (29\% of labels);

- Not indicated quantities or proportions of the recipe ingredients (on all labels);

- is written the date, but not the time of manufacture (35\% of labels);

- is not mentioned the quality of eggs -for preparing creams may be used only the egg diet;

- the correct standard is not mentioned (it is written SM-238 instead of SM 238:2004) (Standardul Moldovei, 2004).

The frequency of use of additives in the technology of cake preparation is represented in Figure 2. In the preparation of dough were used food additives such as: E450 leaving agents (disodium diphosphate) and breeder E 440 (pectin), in the preparation of creams - E 202 curing agent (potassium sorbate), emulsifier E 475 (polyglycerol esters of fatty acids), dye E171 (titanium dioxide).

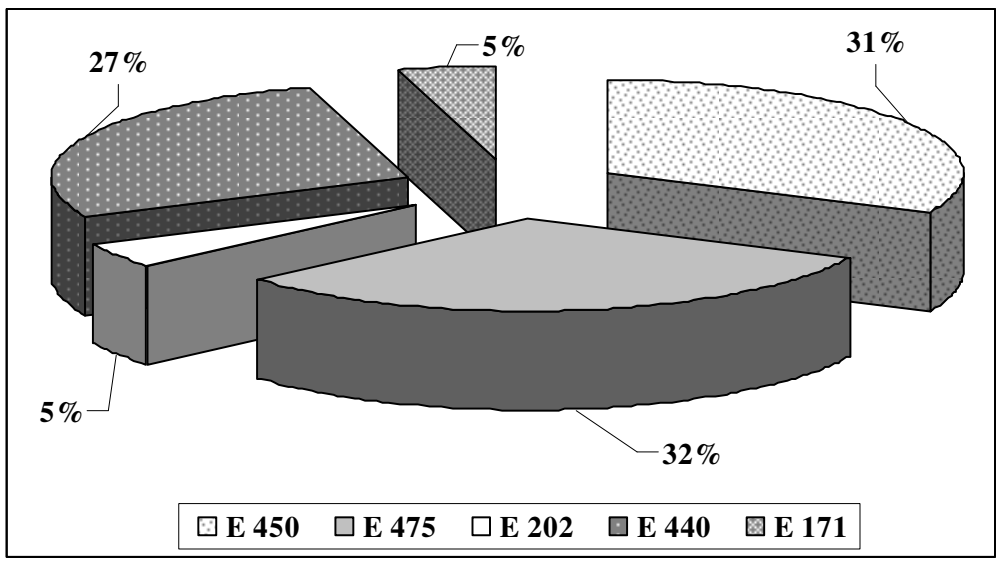

Figure 2. Frequency of use of food additives in the preparation of cakes

\section{CONCLUSIONS}

Authors consider, that nutrition labeling of confectionery products impacts not only on consumers and food industry, but on national trade as well. Comparisons between recent national labeling regulations and confectionery

Vol. XVII (2013), no.2 
products label information, taken with in this study, identify not only challenges to national harmonization that require focused efforts, but also opportunities for improving the quality of the information, provided on the nutrition label.

Proposals concerning improvement of labels for cakes are: exposing the nutritional value of the product in the form of a table; the mention of the concrete name of the additive, but not only E-indication; indicate the quantity of carbohydrate easily assimilated, for cakes that contain honey bees.

\section{ACKNOWLEDGEMENTS}

This work has benefited from the financial support of the project NUTRILAB NUTritional LABeling Study in Black Sea Region Countries (http://nutrilabproject.eu), which has received funding from the European Community's Seventh Framework Programme under project no. 318946 - FP7 PEOPLE - 2012 - IRSES.

\section{REFERENCES}

1. Buteikis L.A. (2006). Tehnologia preparării produselor de patiserie şi cofetărie. Chisinau: Timpul.

2. Hotărîre de Guvern. (2003). Despre aprobarea normelor privind etichetarea produselor alimentare şi normelor privind etichetarea produselor chimice de menaj. HG nr. 996 din 20.08.2003. Monitorul Oficial al RM, 2003, nr. 189-190, art. 1046. Modificat HG 296 din 26.04.11, Monitorul Oficial al Republicii Moldova 74-77/06.05.11, art. 343, HG 1208 din 27.10.08, Monitorul Oficial al Republicii Moldova 198-200/07.11.08 art. 1226; în vigoare: 07.11.09, http://lex.justice.md/index.php?action=view\&view=doc\&lang=1\&id=305 926

3. Hotărîre de Guvern. (2009). Cu privire la aprobarea Reglementării tehnice „Produse de cofetărie”. HG nr. 204 din 11.03.2009. Monitorul Oficial al RM, 2009, nr. 57-58, art. 254; în vigoare: 01.06.2010. http://lex.justice.md/md/331076/

4. Hotărîre de Guvern. (2011). Pentru aprobarea Regulamentului sanitar privind menţiunile nutriţionale şi de sănătate înscrise pe produsele alimentare. HG nr. 196 din 25.03.2011. Monitorul Oficial al RM, 2011, nr. 46-52, art. 229. în vigoare: 01.07.2011. http://lex.justice.md/viewdoc.php?action=view\&view=doc\&id=337965\&1 $\underline{\text { ang }=1}$

Vol. XVII (2013), no.2 
5. Lege de Parlament. (2003). Privind protecţia consumatorilor. LP nr. 105 din 13.03.2003. Monitorul Oficial al RM, 2003, nr. 126-131, art. 507, în vigoare:

28.10.2003. http://lex.justice.md/document_rom.php?id=546986A0:88685EC5

6. Lege de Parlament. (2004). Privind produsele alimentare. LP nr. 78 din 18.03.2004. Monitorul Oficial al RM, 2004, nr. 83-83, art. 431. Modificat LP nr. 318 din 27.12.12, Monitorul Oficial al Republicii Moldova 4955/08.03.13 art. 152, LP nr. 93 din 26.04.12, MO149-154/20.07.12 art. 482; în vigoare: 20.09.12. http://lex.justice.md/index.php?action=view \&view=doc\&lang=1\&id=313 $\underline{238}$

7. Standardul Moldovei. (2004). Torturi, prăjuturi şi rulade. Condiţii tehnice generale. SM 238:2004. Chisinau.

Vol. XVII (2013), no.2 